\title{
Comparative Study of the Sealing Ability of a Polydimethylsiloxane-based Root Canal Sealer
}

\author{
Nickolaos ECONOMIDES \\ Beltes PANAGIOTIS \\ Ioannis KOLOKOURIS \\ Christos GOGOS \\ Ioannis KOKORIKOS \\ Department of Endodontology, Faculty of Dentistry, Aristotle University of Thessaloniki, Thessaloniki, Greece
}

\begin{abstract}
The purpose of this study was to compare the sealing ability of three root canal sealers, RSA (polydimethylsiloxane sealer), Endion (glass-ionomer sealer) and Topseal (epoxy resin sealer), with and without smear layer removal. Ninety extracted human teeth were selected and assigned to 6 groups ( $\mathrm{n}=15)$, according to the following protocols: in 3 groups, the smear layer was left intact and the root canals were obturated with gutta-percha points and RSA, Endion and Topseal, respectively; in the other 3 groups, the smear layer was removed and the root canals were obturated in the same way as described above. Microleakage was measured at 7 days, 1 month and 2 months, using the fluid transport model. The results were expressed in $\mu \mathrm{L} / 24 \mathrm{~h}$. Data were analyzed statistically by Kruskall-Wallis and Mann-Whitney non-parametric tests. The results showed that the Topseal group without smear layer leaked significantly less $(p<0.05)$ than the RSA group without smear layer, at all experimental periods. No statistically significant differences $(p>0.05)$ were found among the other groups, at the established evaluation intervals. The findings of this study showed that the polydimethylsiloxane sealer (RSA) did not yield better sealing ability than the other sealers, either in the presence or in the absence of smear layer. Topseal had the least microleakage from the root canal sealers evaluated.
\end{abstract}

Key words: microleakage, smear layer, root canal sealer.

\section{INTRODUCTION}

Successful root canal therapy requires complete filling of the root canal system with non-irritating biomaterials. It is common knowledge that most endodontic failures are caused by incomplete sealing of the root canals (1). This emphasizes the need for using materials that are able to create a hermetic seal between the root canal system and the periapical tissues. Therefore, microleakage studies on the sealing properties of endodontic materials have played an important role. A wide variety of root filling materials are currently available and standard practice in endodontic therapy has resorted to a combination of gutta-percha points and root canal sealers.

The smear layer is formed on root canal walls as a result of endodontic instrumentation and acts as a barrier to the adaptation and penetration of root canal sealers into dentinal tubules. Although the clinical importance of smear layer removal has not yet been fully understood, it has been shown to improve the interface between the sealer and the root canal dentin, allowing sealer penetration into dentinal tubules, which in turn, leads to microleakage decrease (2-4).

The purpose of this study was to compare the sealing ability of a polydimethylsiloxane root canal sealer (RSA; Roeko, Langenau, Germany) to that of a glassionomer root canal sealer (Endion; Voco, Cuxhaven, Germany) and a resin-based root canal sealer (Topseal; Dentsply, Konstanz, Switzerland), with and without removal of smear layer. The fluid transport model was used for microleakage assessment.

\section{MATERIAL AND METHODS}

Ninety single-rooted human teeth, which had 
been extracted for periodontal or prosthetic reasons, were selected and stored in distilled water. Crowns were removed using a high-speed bur with water spray cooling, in such a way that all roots were about 14-15 $\mathrm{mm}$ long.

The root canals were instrumented with $\mathrm{K}$-files and Hedstrom files (Dentsply/Maillefer, Ballaigues, Switzerland) using the step-back technique. The working length was established at the same level for all specimens using a \#25 master apical file. Root canals were irrigated with 5\% sodium hypochlorite at each change of instrument. All specimens were prepared to a $\# 55 \mathrm{~K}$-file.

After root canal instrumentation, the teeth were assigned to 6 groups ( $\mathrm{n}=15$ ), according to the following protocols: in 3 groups, the smear layer was left intact and the root canals were filled with RSA Endion and Topseal sealers, respectively; in the other 3 groups, a final irrigation with $17 \%$ EDTA was used to remove the smear layer and the root canals were filled with the same materials.

All tested materials were mixed and inserted into the canals according to manufacturers' instructions. The 90 roots were obturated by the same operator with gutta-percha points using the lateral condensation technique.

Microleakage was assessed after 7 days, 1 and 2 months, and the specimens were stored in distilled water at $37^{\circ} \mathrm{C}$ at the time intervals. The method used to measure fluid transport has been previously described in the literature (5). The root sections were placed in the junction of two lengths of plastic tubing, the joint being sealed with silicone to prevent leakage. Any liquid passing through the tube had to pass through the specimen into the second tube. The tubes were filled with distilled water from either side of the specimen and a standard glass capillary tube was connected to the plastic tube on the outlet side of the specimen. Using a syringe, water was sucked back ( $3 \mathrm{~mm}$ into the open end of the glass capillary) creating an air bubble. The whole set-up was placed in a water bath $\left(20^{\circ} \mathrm{C}\right)$ and, using the syringe, the air bubble was adjusted to a suitable position within the capillary. Then a pressure of $0.2 \mathrm{Atm}$ from the inlet side was applied to force the water through the voids along the filling, thus displacing the air bubble in the capillary tube. The volume of the fluid transport was measured by observing the movement of the air bubble. The displacement of the air bubble was recorded as the fluid transport results (L), expressed in $\mu \mathrm{L} / 24 \mathrm{~h}$.

Data were analyzed statistically by KruskallWallis and Mann-Whitney non-parametric tests.

\section{RESULTS}

At 7 days (Table 1), the Topseal group without smear layer leaked significantly less $(p<0.05)$ than the RSA group without smear layer. Nevertheless, no statistically significant differences $(p>0.05)$ were found among the other groups. Similar results were observed at the 1-month and 2-month evaluations (Tables 2 and 3).
Table 1. Microleakage of the root canal sealers after 7 days.

\begin{tabular}{lccccc}
\hline & $\mathrm{L}=0$ & $0<\mathrm{L} \leq 10$ & $10<\mathrm{L} \leq 20$ & $\mathrm{~L}>20$ & $\begin{array}{c}\text { Mean } \\
(\mu \mathrm{L} / 24 \mathrm{~h})\end{array}$ \\
& & & & & \\
\hline With smear layer & & & & & \\
$\quad$ RSA & 1 & 4 & 3 & 7 & 15.20 \\
$\quad$ Endion & 0 & 4 & 5 & 6 & 15.13 \\
$\quad$ Topseal & 1 & 4 & 6 & 4 & 12.00 \\
Without smear layer & & & & & \\
$\quad$ RSA & 0 & 1 & 9 & 5 & 16.73 \\
$\quad$ Endion & 2 & 4 & 5 & 4 & 12.87 \\
$\quad$ Topseal & 2 & 6 & 4 & 3 & 10.87 \\
\hline
\end{tabular}

Data are reported as number of specimens. $\mathrm{L}=$ Fluid transport results, expressed in $\mu \mathrm{L} / 24 \mathrm{~h}$.

Table 2. Microleakage of the root canal sealers after 1 month.

\begin{tabular}{|c|c|c|c|c|c|}
\hline & $\mathrm{L}=0$ & $0<\mathrm{L} \leq 10$ & $10<\mathrm{L} \leq 20$ & $\mathrm{~L}>20$ & $\begin{array}{c}\text { Mean } \\
(\mu \mathrm{L} / 24 \mathrm{~h})\end{array}$ \\
\hline \multicolumn{6}{|c|}{ With smear layer } \\
\hline RSA & 1 & 1 & 3 & 10 & 16.87 \\
\hline Endion & 0 & 3 & 3 & 9 & 16.93 \\
\hline Topseal & 1 & 3 & 5 & 6 & 14.07 \\
\hline \multicolumn{6}{|c|}{ Without smear layer } \\
\hline RSA & 0 & 1 & 5 & 9 & 18.13 \\
\hline Endion & 0 & 4 & 5 & 6 & 15.87 \\
\hline Topseal & 2 & 5 & 3 & 5 & 12.80 \\
\hline
\end{tabular}

Data are reported as number of specimens. $\mathrm{L}=$ Fluid transport results, expressed in $\mu \mathrm{L} / 24 \mathrm{~h}$. 


\section{DISCUSSION}

Several methods have been used to investigate the sealing ability of root canal sealers. Fluid transport model, proposed by $\mathrm{Wu}$ et al. (6), offers several advantages over more commonly used techniques for microleakage assessment. It has been suggested that the fluid transport model is both highly reproducible and more sensitive than dye penetration for detection of fulllength voids along root canal (7). In addition, this method does not destroy the specimens, which means that it is possible to assess microleakage at different time intervals over extended periods using the same specimen (8). Leakage should be assessed not only immediately after sealing but also over time because sealing needs to be long lasting to be clinically effective (9).

Smear layer removal has been the focus of several studies aimed at optimizing chemomechanical preparation of the root canal system and has been referred to reduce microbial flora and enhance the sealing properties of root canal filling materials (10-12)

The results of this study showed that, from the root canal sealers evaluated, Topseal had the least microleakage. At all experimental periods, Topseal leaked significantly less than RSA when the smear layer was removed. No statistically significant differences were found among all other groups. Topseal is an epoxy resin-based sealer and the marginal seal of resin-based cements has been proved to be superior to that of other cements (13). Haikel et al. (14) evaluated the apical seal obtained with three commonly used root canal cements (Sealapex, Topseal and Sealite), using a method based

Table 3: Microleakage of the root canal sealers after 2 months.

$\mathrm{L}=0 \quad 0<\mathrm{L} \leq 10 \quad 10<\mathrm{L} \leq 20 \quad \mathrm{~L}>20 \quad \begin{gathered}\text { Mean } \\ (\mu \mathrm{L} / 24 \mathrm{~h})\end{gathered}$

\begin{tabular}{lrrrrr}
\hline With smear layer & & & & & \\
RSA & 0 & 2 & 3 & 10 & 17.47 \\
Endion & 0 & 2 & 4 & 9 & 17.20 \\
Topseal & 0 & 2 & 7 & 6 & 14.93 \\
& & & & & \\
Without smear layer & & & & & \\
RSA & 0 & 0 & 4 & 11 & 19.00 \\
Endion & 0 & 2 & 5 & 8 & 15.87 \\
Topseal & 1 & 3 & 6 & 5 & 13.80 \\
& & & & & \\
\hline
\end{tabular}

Data are reported as number of specimens. $\mathrm{L}=$ Fluid transport results, expressed in $\mu \mathrm{L} / 24 \mathrm{~h}$. on the quantitative analysis of I-radiolabeled lysozyme penetration. Topseal and Sealapex showed similar leakage behavior over time, with Topseal producing numerically better results. Sealite showed acceptable leakage up to the 14th day, after which sealing deteriorated significantly.

RSA is a polydimethylsiloxane-based sealer, which is, according to the manufacturer, a biocompatible and insoluble root canal filling material. Wu et al. (15) determined the long-term sealing ability of RSA sealer, using 80 extracted human mandibular premolars assigned to 4 groups. Specimens in group 1 were obturated with laterally compacted gutta-percha points and RSA. In the other groups, vertically compacted warm gutta-percha was used together with either RSA (group 2), Pulp Canal sealer (group 3) or no sealer (group 4). Using the fluid transport model, leakage along root fillings was measured before and after post-space preparation. Before and after post-space preparation, groups 1 and 2 leaked significantly less than groups 3 and 4, whereas no significant difference existed between RSA groups.

Glass-ionomer sealers were introduced into root canal treatment protocol because of their adhesion to hard dental tissues (16). There is still little information available on the sealing ability of Endion glass-ionomer based sealer. In the present study, Endion had intermediate microleakage values and did not differ statistically from the other sealers. Ketac-Endo is another glass-ionomer cement developed for endodontic use. In a previous study, Almeida et al. (17) evaluated the apical sealing ability of Ketac-Endo, AH-plus (epoxy resin sealer) and Fill Canal (zinc oxide-eugenol sealer) using the dye penetration method. Statistical analysis revealed no significant difference in terms of microleakage between Fill Canal and Ketac-Endo. AH-plus had significantly less leakage than the other sealers.

The findings of this study showed that the polydimethylsiloxane sealer (RSA) did not yield better sealing ability than the other sealers in either presence or absence of smear layer. Topseal had the least microleakage from the root canal sealers evaluated.

\section{RESUMO}

O objetivo deste estudo foi comparar a capacidade de selamento de três cimentos endodônticos, RSA (cimento à base de silicone), Endion (cimento à base de ionômero de vidro) e Topseal (cimento à base de resina epóxica), com e sem remoção de smear layer. Noventa dentes humanos 
extraídos foram selecionados e distribuídos em 6 grupos $(\mathrm{n}=15)$, de acordo com os seguintes protocolos: em 3 grupos, a smear layer foi mantida e os canais radiculares foram obturados com cones de guta-percha e com os cimentos RSA, Endion e Topseal, respectivamente. Nos outros 3 grupos, a smear layer foi removida e os canais radiculares foram obturados da mesma forma. A microinfiltração foi avaliada aos 7 dias, 1 mês e 2 meses, utilizando o sistema de transporte de fluído. Os resultados foram expressos em $\mu \mathrm{L} / 24 \mathrm{~h}$. Os dados foram analisados estatisticamente por meio dos testes não-paramétricos de Kruskall-Wallis e MannWhitney. Os resultados demonstraram que o grupo obturado com Topseal sem smear layer apresentou infiltração significativamente menor $(\mathrm{p}<0.05)$ que o grupo obturado com cimento RSA sem smear layer, em todos os períodos avaliados. Não houve diferença estatisticamente significante $(p>0.05)$ entre os outros grupos, nos intervalos de avaliação estabelecidos. Os achados deste estudo demonstraram que o cimento à base de silicone (RSA) não apresentou melhor capacidade de selamento que os outros cimentos, na presença ou ausência de smear layer. Dentre os cimentos endodônticos avaliados, o Topseal apresentou os menores valores de microinfiltração.

\section{REFERENCES}

1. Ingle JI, Taintor JF. Endodontics. 3rd ed. Philadelphia: Lea \& Febiger; 1985.

2. White RR, Goldman M, Lin PS. The influence of the smeared layer upon dentinal tubule penetration by plastic filling materials. J Endod 1984;20:18-21.

3. Oksan T, Aktener BO, Sen BH, Tezel H. The penetration of root canal sealers into dentinal tubules. A scanning electron microscopy study. Int Endod J 1993;26:301-305.

4. Sen BH, Piskin B, Baran N. The effect of tubular penetration of root canal sealers on dye microleakage. Int Endod J 1996;29:23-28.

5. Pashley DH, Andringa HJ, Derkson GD, Derkson ME, Kalathoor SR. Regional variability in the permeability of human dentine. Arch Oral Biol 1987;32:519-523.
6. Wu MK, De Gee AJ, Wesselink PR, Moorer WR. Fluid transport and bacterial penetration along root canal fillings. Int Endod J 1993;28:185-189.

7. Wu MK, De Gee AJ, Wesselink PR. Fluid transport and dye penetration along root canal fillings. Int Endod $J$ 1994;27:233-238.

8. Wu MK, De Gee AJ, Boersma J. A 1-year follow up study on leakage of four root canal sealers at different thickness. Int Endod J 1995;28:185-189.

9. Miletic I, Ribaric SP, Karlovic Z, Jukic S, Bosnjak A, Anic I. Apical leakage of five root canal sealers after one year of storage. J Endod 2002;28:431-432.

10. Cergneux M, Ciucchi B, Dietschi JM, Holz J. The influence of the smear layer on the sealing ability of canal obturation. Int Endod J 1987;20:228-232.

11. Economides N, Liolios E, Kolokuris I, Beltes P. Long-term evaluation of the influence of smear layer removal on the sealing ability of different sealers. J Endod 1999;25:123-125.

12. Sousa-Neto MD, Passarinho-Neto JG, Carvalho-Junior JR, Cruz-Filho AM, Pecora JD, Saquy PC. Evaluation of the effect of EDTA, EGTA and CDTA on dentin adhesiveness and microleakage with different root canal sealers. Braz Dent J 2002; 13:123-128.

13. Oguntebi BR, Shen C. Effect of different sealers on thermoplasticized gutta-percha root canal obturations. J Endod 1992;18:363-366.

14. Haikel Y, Wittenmeyer W, Bateman G, Bentaleb A, Allemann C. A new method for the quantitative analysis of endodontic microleakage. J Endod 1999;25:172-177.

15. Wu MK, Tigos E, Wesselink PR. An 18-month longitudinal study on a new silicon-based sealer, RSA RoekoSeal: a leakage study in vitro. Oral Surg Oral Med Oral Pathol Oral Radiol Endod 2002;94:499-502.

16. Powis DR, Folleras T, Merson SA, Wilson AD. Improved adhesion of a glass-ionomer cement to dentin and enamel. J Dent Res 1982;61:1416-1422.

17. De Almeida WA, Leonardo MR, Tanomaru Filho M, Silva LA. Evaluation of apical sealing of three endodontic sealers. Int Endod J 2000;33:25-27.

Accepted April 28, 2004 